\title{
South Africa's Increased Matriculation Passes: What Skunks behind the Rose?
}

\author{
Lebusa Monyooe $^{1}$, Martin Tjatji ${ }^{2} \&$ Eulenda Mosese ${ }^{1}$ \\ ${ }^{1}$ Grants Management and Systems Administration, National Research Foundation, South Africa \\ ${ }^{2}$ Reviews and Evaluations, National Research Foundation, South Africa \\ Correspondence: Lebusa Monyooe, Director, Grants Management and Systems Administration Directorate, \\ National Research Foundation, South Africa. E-mail: Lebusa@nrf.ac.za
}

Received: September 9, 2013

doi:10.11114/jets.v2i1.278
Accepted: September 20, 2013 Online Published: November 11, 2013

URL: http://dx.doi.org/10.11114/jets.v2i1.278

\begin{abstract}
This article argues that the exponential increases in the Grade 12 (Matriculation) passes post 1994 do not necessarily translate to quality because of the low performance norms and standards set for passing Grade 12 . It further calls for a serious reflection and interrogation of existing policies on performance, benchmarks, teacher education programmes, school leadership and governance in a highly unionized school environment. An overhaul of the provisioning and management modalities is required to enhance South Africa's competitiveness in the knowledge economy.
\end{abstract}

Keywords: matriculation performance, alliance and unionization, policy frameworks, teacher education, South African provinces, curriculum development, assessment tests, quality assurance, school governance, leadership.

\section{Acronymns}

DBE

Department of Basic Education

DHET

Department of Higher Education and Training

NEPA

National Education Policy Act

SASA

South African School Act

NDP

National Development Plan

NGO

Non-Governmental Organisation

ANA

Annual National Assessments

PISA

Programme in International Student Assessment

TIMSS

Trends in International Mathematics and Science Study

CAPS

Curriculum and Assessment Policy Statement

SAQA

South African Qualifications Authority

ISPFTED

Integrated Strategic Planning Framework for Teachers Education and Development

TED

Teacher Education and Development

OECD

Organization for Economic Cooperation and Development

NRF

National Research Foundation (South Africa)

\section{Introduction}

It was a fine morning for indulgence in matters of less intuitive rigour or engagement, when suddenly, our attention was caught by a street vendor's poster with a catchy and paradoxical inscription "Chaos and Jubilation at Schools". A flurry of tentative meanings traversed our minds. We wondered if:

- There was imminent industrial strike by teacher unions and learners were just happy to stay idle?

- Learners struggled to find transport to school on the first day schools opened?

- The Minister of Basic Education had decided to change school calendar and deferred the opening date for schools? 
It turned out that it was the start of a new schooling year calendar. South African parents had invaded schools to secure school admission for their children. The poster's contrasting inscription captured the mood of the day. It was 'jubilation' for those admitted to schools and 'chaos' for the unsuccessful ones. Inadequate resourcing has over the years led to many learners failing to go to school (Annual Report 2008/09). The paucity of adequate classrooms has undermined the quality of educational provisioning. Failure to correct the situation has created public discontent, especially when the government has declared education the 'apex' of government.

Eighteen years into democracy, South Africa's basic education still grapples with historical and systemic imbalances. Many policies implemented have not advanced educational transformation robust enough. In fact, the quality of education and its concomitant performance standards do not favourably compare with international benchmark regimes. Issues of governance continue to plague the system, for instance, finding balance between teacher professionalism and unionization (Letseka, et al 2012).

Learner performance in international assessment tests such as the Trends in International Mathematics and Science Study (TIMSS) confirms that South Africa lags behind. Other areas of concern include policy implementation, performance benchmarks for matriculation, school governance and management. New perspectives on plausible strategies to improve quality education and provisioning are urgently needed to enhance the country's competitiveness in the global arena.

\section{Policy and Legislative Pillars}

The South African Constitution stipulates unambiguously in section 29(i) that "everyone has the right to (i) a basic education, including adult basic education, and (ii) further education, which the state, through reasonable measures, must make progressively available and accessible, (The South African constitution Act 108 of 1996) The right to basic education is further articulated in sections 9(2), (3), (4) and (5) which commits the South African government to achieve the principles of equality and non-discrimination across the education and training sector". The government is obligated to provide quality and a "unified system of education and training".

Major strides have made in terms of policy formulation and implementation. The demarcation of roles and responsibilities between departments of basic education and higher education and training has been clarified through legislation. For instance, the National Education Policy Act (1996) encourages close cooperation and partnership between national and provincial authorities. Whilst the National Education Act (NEA) recognizes improved corporate governance across all tiers of governance, the South African Schools Act (SASA) of 1996 delineates school governance and management.

The SASA recognizes the right of learners to quality education irrespective of race, gender and creed. Although the policy declares schooling to be compulsory for children aged 5 to 16 years, the government has failed to enforce and comply with the legal requirement. Many children still stay out of schools.

The South African Department of Education Annual Report (2008/09) cites poverty as the major cause for non-compliance by parents in rural and townships areas. The financial demands at the National Treasury make access to universal primary education in the nine South African provinces unachievable. Some successes have been notched in the form of policies post 1994, for instance:

- The National Strategy for Further Education and Training (1999 - 2001);

- The Employment of Educators Act (1998);

- The Education White Paper on Early Childhood Development (2000);

- The National Curriculum Statement(Grades R -12);

- The Education White Paper 6 on Inclusive Education (2001);

- Action Plan to 2014: Towards Realisation of Schooling 2025;

- The Delivery Agreement for the Basic Education Sector (2010) etc.

There has been a relative improvement towards quality education across all sectors tasked with education.

The above mentioned policies do not bring instant success and quality to education on their own accord. The secret is in their seamless implementation and monitoring to ensure that they achieve envisaged changes and targets (improvements). It will take South Africa a longer time to fully address current historical and systemic imbalances. In an article titled "Rethinking the building blocks", Prew (2012) decries about policy maladies that have perpetuated a narrow perspective about the role of education. He challenges governments to "reimagine schooling so that it does not serve the elite, but also ensures that all children leave school literate and numerate". 
South Africa's education system bears similar characteristics, for instance, learners perform dismally in international assessment tests in literacy and numeracy.

The downward spiralling of learner performance must be arrested to enhance the country's chances of being competitive in the knowledge economy. According to Education Annual Report 2008/09, "Skills development, as well as improving the relevance of education, with regard to employment and job creation, had to be strengthened". Efficacious education systems like the Finnish and Singaporean have implemented policies that enhance the quality and performance of education.

Sahlberg (2011) credits the Finnish successes to: "Education policies that are based on the ideal of equal educational opportunities and that have brought teachers to the core of educational opportunities have positively impacted the quality of learning outcomes" (p37).

The adoption of the National Development Plan 2030 provides an opportunity for South Africa to explore other strategies that would enhance quality of education. The plan though ambitious attempts to achieve the following key objectives:

- High quality, universal early childhood education;

- Quality school education, with globally competitive literacy and numeracy standards;

- Further and higher education and training that enables people to fulfil their potential;

- An expanding higher education sector that can contribute to rising incomes, higher productivity and the shift to a more knowledge-intensity economy; and

- A wider system of innovation that links universities, science councils and other research and development role players with priority areas of the economy (NDP, p38).

Whilst the plan makes the right nuances about 'quality education' and 'global economic competitiveness', the devil lies in the details of what constitutes quality and global competitiveness and concomitant modus operandi.

Tomasevski (2003:18) offers an insight approach to education namely that:

For education to be adaptable, schools must adjust to the children's needs in accordance with the principle of the best interests of every child. This change ended the practice of forcing children to adapt to whatever school was offered to them. Human rights being indivisible, the requirement of adaptability means that human rights must be protected within education system and also improved through education.

Tomasevski (2003) raises two crucial principles regarding organizational engagement, namely, adaptability and relevance. A perspective also shared by Prew (2012), who argues "If schooling in Africa was a commercial enterprise, it would have been closed down because of low output and low levels of efficiency". It is a plausible observation that needs further analysis through the interrogation of existing research data (education black box). South Africa has not exhaustively mined educational data at its disposal to correct system's deficiencies.

Intelligent use of data is crucial for all sectors of governance. The invention of the cockpit recorder and flight data recorder -commonly known as the 'black box' by Dr David Warren in 1953 revolutionized the aviation industry. It became a standard operating procedure for airlines given its invaluable data (black box) on crash investigations and overall management of the sector. Similarly, digitally driven companies like Google and Amazon have refined data management strategies and utilization to enhance commercial viability and global competitiveness. Intelligent use of data (black box) can enhance organizational operations, decision-making, performance target setting and monitoring.

According to Mwamwenda and Lukhele-Olorunju (2013) Africa's undoing in education has been a scant use of the research intelligence (black box) at its disposal. South Africa has not optimally tapped into the existing education research intelligence to correct existing systemic imbalances crippling education system. Like the airlines and digitally driven organizations, South Africa needs to strategically strengthen its data mining, management and deployment to enhance quality across all sectors.

The exponential increases in the number of matriculation passes post 1994 has generated mixed perspectives. The department of basic education perceives the increase as a major achievement. Whilst it is plausible to agree with the department's observation, it suffices to argue that there is some 'skunk' behind the rosy matriculation passes. For instance, South Africa's benchmarks for performance are below international performance regimes. There is a need to explore alternatives performance regimes that would enhance quality. 


\section{1) Matriculation results: what skunks behind the rose?}

The exponential increases in the South Africa's matriculation results post 1994 has generated mixed reactions, for instance, whilst the government is quite buoyant about improved results, it has not drawn positive reaction from education analysts and critics because of the very low performance standards set to pass matriculation. Section 2 below provides a comparative analysis of the 2011 and 2012 matriculation results.

\section{2) Graphical Analysis of South Africa's matric pass rate 2011 - 2012}

Figure 1.1 below shows that the Western Cape Province received highest pass rate in South Africa in 2011. This Province received $83 \%$ pass rate in the said year. It was followed by the Gauteng Province, which achieved $81 \%$. North West and Free State Provinces however, fell under the top five (5) provinces that obtained pass rates above 70\%. This was followed by Northern Cape, KwaZulu Natal (KZN), Mpumalanga and Limpopo. These provinces managed with an average of up to $60 \%$.The Eastern Cape Province requires appropriate interventions to improve 58\% pass rate achieved in 2011.

The graph further shows that, in 2012, Gauteng, Western Cape, Free State, and North West Provinces were the highest Provinces that received $80 \%$ and above pass rate in South Africa. These provinces archived 84\%, 83\%, $81 \%$ and $80 \%$ pass rate respectively. These were followed by Northern Cape, Mpumalanga and KZN. These Provinces managed to achieve $75 \%, 70 \%$ and $73 \%$ pass rates. Limpopo and Eastern Cape Provinces scored the least percentages in the said year, which were $67 \%$ and $62 \%$. In general, the Eastern Cape Province did not achieve the best result in SA, in comparison to other provinces. The analysis of contextual factors that led to these variances cannot be extrapolated from the matriculation data discussed in this paper.

A comparative analysis of the 2011 and 2012 matriculation results shows that the pass rate in the Gauteng and Limpopo Provinces both increased by 3\% from 2011 to 2012. During these years, 64\% and 67\% were achieved in the Limpopo Province respectively. The pass rate in Gauteng was $84 \%$ during the year 2012 and this represent a $3 \%$ higher compared to a pass rate of $81 \%$ in 2011 . There has been consistency in the pass rates in the Western Cape Province. This was $83 \%$ in both 2011 and 2012. A mere $2 \%$ increase was achieved by the North West Province from 2011, which was 78\% and $80 \%$ in 2012.

Progress was made in the Northern Cape Province. This Province achieved a pass rate of $69 \%$ and $75 \%$ in 2011 and 2012 respectively. This represents a year on year increase of 6\%. There was a $4 \%$ improvement in the Eastern Cape Province. In 2011, 58\% was achieved by Eastern Cape and this increased to $62 \%$ the following year.

Free State, Mpumalanga and KZN Provinces both improved their pass rates by 5\% between 2011 and 2012. In 2011 and 2012, (76\% and 81\%); (65\% and 70\%) and (68\% and 73\%) were observed in these provinces respectively.

Generally, there has been an average improvement in the pass rate in the SA nine (9) provinces over the period between 2011 and 2012. This contrasts sharply with the pass rate of learners enrolled in private schools.

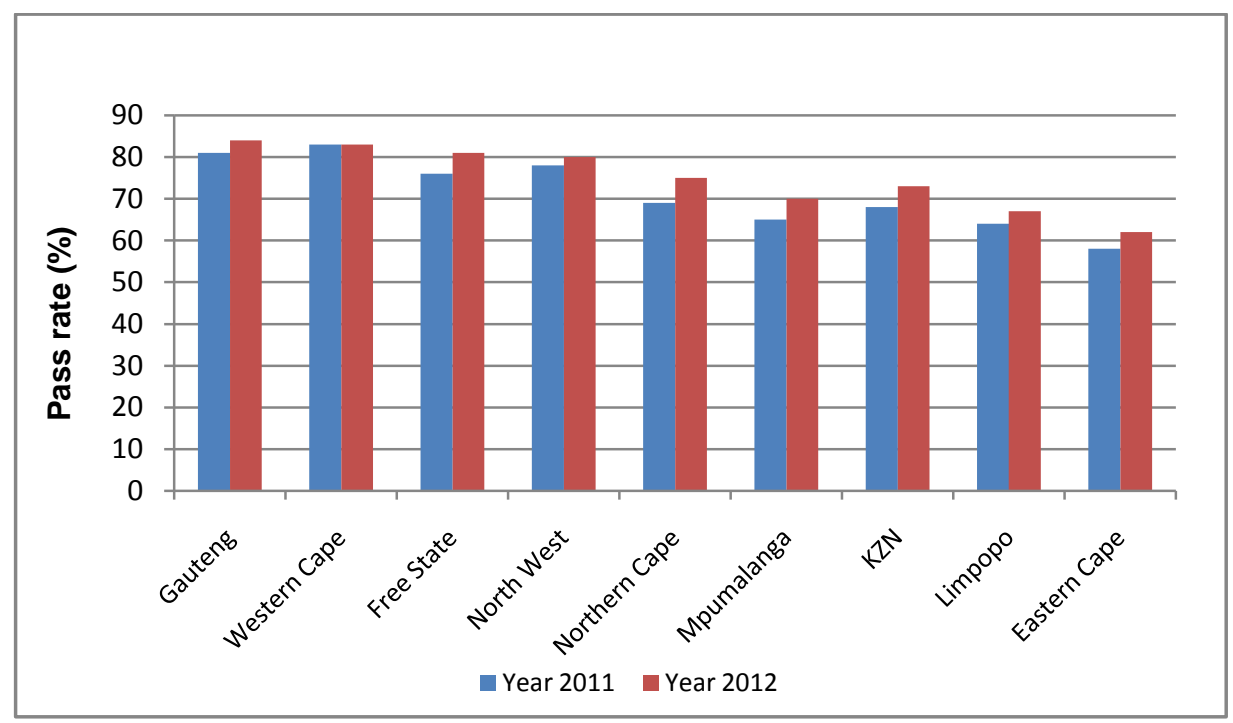

Figure 1. Pass rate in nine (9) provinces of South Africa for the period 2011 to 2012

Source: Report on the 2011-2012 National Senior Certificate Examination results, DBE (January 2012 and January 2013) 
As shown in Figure 1.2 below, the national pass rate was about $70 \%$ during the year 2011 and this increased slightly to $73.9 \%$ in 2012 . This represents a year on year increase of $3.9 \%$. The figure further indicates that in private schools, a mere $0.05 \%$ was achieved from $2011(98.15 \%)$ to $2012(98.20 \%)$. This does not appear to be a 'train smash' at all since this might be considered to be best results given the low performance bar set for matriculation.

Comparing private schools with public schools will lead to the conclusion that, in private school, the pass rate in 2011 was $28.15 \%$ higher than that of public schools, and in 2012, 24.3\% was achieved in private schools against the public schools

In general, the figure generally shows that private schools achieve high pass rate than public schools in the period under discussion.

Of the total number of national pass rate of learners who passed matric in $2011(70 \%)$ only about $24 \%$ qualified to enrol for university degree, $46 \%$ of these students qualified to engage in maths related courses at the university, and $53 \%$ managed to qualify for Physical Science courses. In 2012, there was an improvement in these cases, $27 \%$ out of $73.9 \%$ qualified for a university entry, $54 \%$ of these for maths enrolment and $61 \%$ for physical science enrolment.

Of the total number of private pass rate of learners who passed matric in $2011(81.67 \%)$ qualified for university enrolment. In 2012, 83.6\% qualified for university enrolment. This represents a 1.93\% increase from 2011 to 2012.

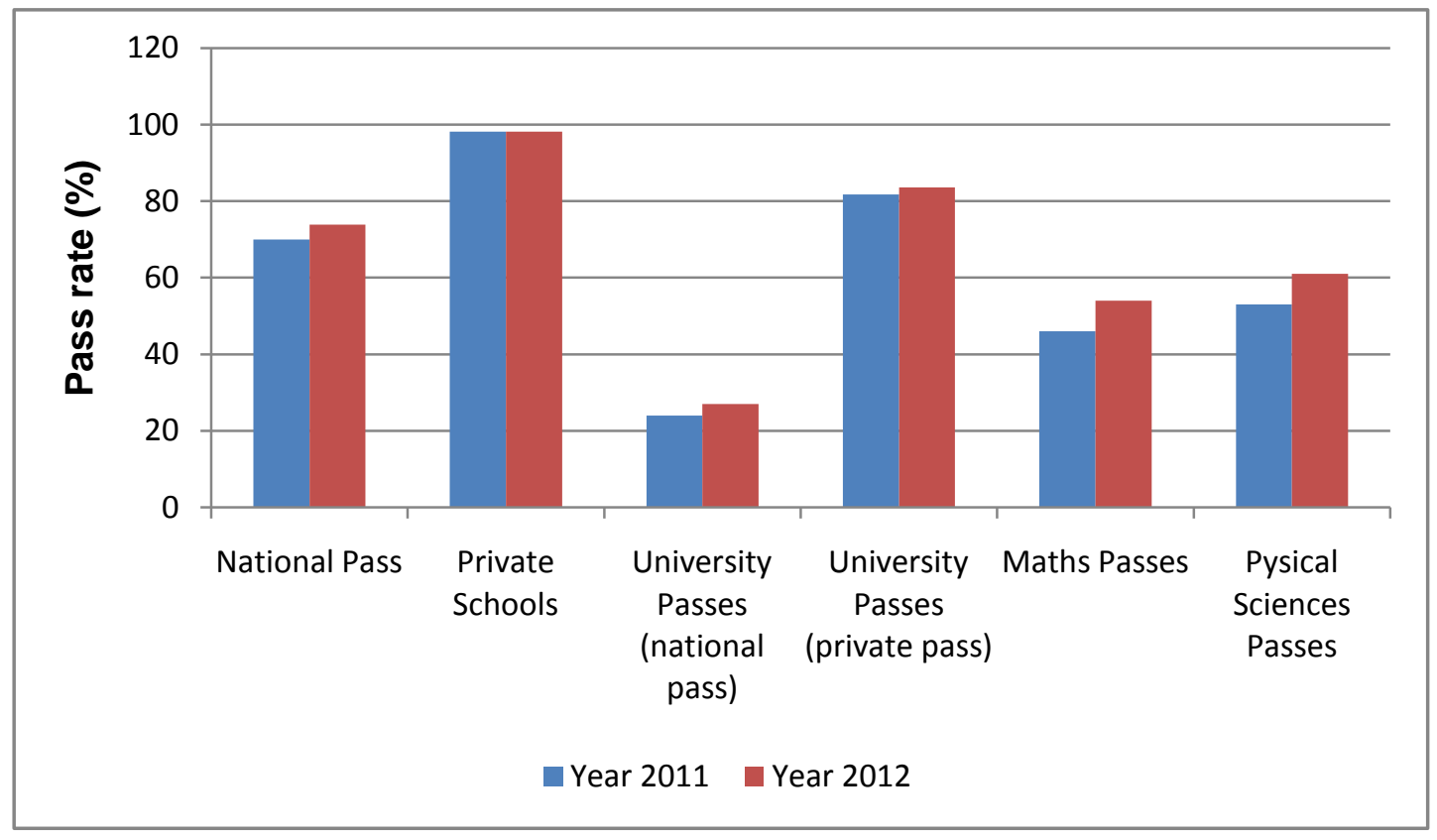

Figure 2. National pass rate vs different categories

Source: Report on the 2011-2012 National Senior Certificate Examination results, DBE (January 2012 and January 2013)

\section{Benchmarking and Performance Standards Conundrum}

South Africa's performance in International assessment tests such as TIMSS has been dismal when compared with other nations, especially in literacy and numeracy. When South Africa tested the grades 1 to 6 learners in 2011 through the Annual National Assessments (ANA), the performance was equally dismal, for instance, "In Grade 3, the national average performance in Literacy, stands at 35\%. In Numeracy our learners are performing at an average of 28\%. Provincial performances in these two areas is between $19 \%$ and $43 \%$, the highest being the Western Cape, and the lowest being Mpumalanga”. The situation in grade 6 was equally poor because the "national average performance in Languages is $28 \%$. For Mathematics the average performance is $30 \%$. Provincial performance in these two areas ranges between $20 \%$ and $41 \%$, the highest being the Western Cape and the lowest being Mpumalanga".

The adoption of the ANA by the DBE was seen as a plausible intervention to obtain baseline data on school performance and learner progression across grades. Similar sentiments have been captured by the South African 
Department of Education Annual Report 2008/09. It inter alia, reiterates that the tests would lay a solid foundation at the primary school level to enhance quality education. The report makes a bold expectation that "by 2011 no learner would attain an aggregate score of less than 50\% in these standardised assessments". Regrettably, the current scholastic performance still lags behind the anticipated performance target due to a myriad of challenges. South Africa needs responsive interventions to turn schools into hubs for excellence.

The importance and need to uphold reputable educational benchmarking regimes has been cleverly delineated by Darling-Hammond and Wentworth (2010) who argue that:

High-performing nations integrate curriculum, instruction, and assessment to improve both teaching and learning. As a large and increasing part of their examination systems, they use open-ended performance tasks and school-based assessments to give students opportunities to develop $21^{\text {st }}$ century skills: The ability to find and organize information to solve problems, frame and conduct investigations, analyze and synthesize data, and apply to new situations.

According to Darling-Hammond and Wentworth (2010:1) the publication of "A Nation at Risk in 1983" changed the educational landscape in the United States of America in that it created robust debates about assessment tools. They argue that although there was significant proliferation and use of standardized tests, it did not bring instant success and quality as the "United States has fallen further behind on international assessments of student learning". They further argue that "On the Program in International Student Assessment (PISA) tests in 2006 , the United States ranked $25^{\text {th }}$ of 30 OECD countries in mathematics and $21^{\text {st }}$ of 30 in sciences, a decline in both raw scores and ranking from three (3) years earlier". The United States students also scored lowest "on problem-solving items" than their counterparts, such as Finland, Canada, Australia, New Zealand, Hong Kong, Korea, and Japan. The PISA assessment tools test students' ability to apply mathematical, scientific and reading skills (proficiency) to solve scholastic problems. The American students were found wanting in skills proficiency because of the multiple-choice assessment preferred by the American education system.

The efficacy of performance regimes as delineated by Darling-Hammond and Wentworth (2010) above does not resonate with the South Africa's performance norms and standards across the grades but specifically the matriculation. There are contrasting experiences between South Africa and high performing nations on inter alia, integration of curriculum, teaching and assessment methodologies. South Africa's obsession with terminal examinations has turned schools into sites for unhealthy competition to achieve $100 \%$ passes at matric level. Teachers devote time on advancing passes irrespective of whether learners do actual have the requisite proficiencies to pass. Learning becomes mechanical and encourages rote learning. It is critical to reflect on the efficacy of the current educational policies on quality assurance and the extent to which they have been optimally implemented.

In terms of the General and Further Education and Training Quality Assurance Act (2001), uMalusi remains the designated council for quality assurance. Its scope of work according to the 2008/09 Annual Report includes:

Ensuring continuous quality improvement in the delivery and outcomes of the general and further education and training sectors of the national education and training system, by monitoring the suitability and adequacy of standards and qualification, accrediting private providers; assuring the quality of learner assessments at exists points; issuing certificates; promoting quality among providers of education, training and assessment (p237).

South Africa's performance norms for grade 12 (matriculation) require learners to achieve " 40 percent in home language, 40 percent in two other subjects, and 30 percent in three subjects". The raw learners' raw scores then get standardized by uMalusi to mitigate contextual factors and for quality assurance. The uMalusi's standardization processes and procedures are contentious because of lack of clarity on the criteria used and selected subjects. Failure to disclose the standardization modus operandi creates confusion and further strengthens scepticisms about the efficacy of the system and quality of the standardized passes.

The reality is that South Africa's performance regimes across all grades do not compare favourably with international and continental standards for exit examinations. South Africa's $73.9 \%$ national pass rate does not denote quality performance given the low bar set to pass matriculation (Monyooe, 2013). It has serious implications for learners when they enrol for tertiary studies. If it is not addressed, it will perpetuate academic mediocrity and arrest the country's global competitiveness in the knowledge economy. South Africa's poor performance in Maths and Science at Grade 9 as evidenced by the Trends in International Mathematics and Science Study (TIMSS) does not compare with top-performing countries like Finland, Singapore, Hong Kong, Taiwan and Japan. 
Setting low performance regimes and standards under compensates education. South Africa needs to drive debate around performance regimes and concomitant setting procedures to ensure that only plausible and effective regimes are implemented to enhance quality. Such debates should factor in diverse economic quintiles that invariably impact on quality and provisioning of educational activities. A holistic approach would advance plausible strategies to mitigate inherent systemic imbalances across the nine provinces of South Africa.

Robust engagement about educational benchmarking regimes and strategies would unravel the 'skunk' behind the 'rosy' exponential increase in matriculation since post 1994. That way, South African schools might progress to what Ayers (2010) terms "laboratories for discovery and surprise, spaces where children can be active". It is a process that requires better planning, leveraging of resources and meticulous implementation and monitoring to enhance quality and performance in general. Reckless adoption of standardized assessment tests would not bring instant success and quality.

According to Ayers (2010) "standardized tests are plagued with inherent and intractable problems". He instead, recommends use of "authentic assessment strategies [to] move away from tests that stand as surrogates for the real world and assume that the real world matters". The differentiated benchmarking might not bring quality. They should be better coordinated to enhance effective integration of curriculum, teaching and assessment methodologies. The seamless integration has the potential to improve school performance and learner achievement.

According to Darling-Hammond and Wentworth (2010:2) the secret to quality education is associated with the application of "project-based, inquiry-oriented learning... mapped to syllabus" to challenge teachers and learners to breach knowledge boundaries. South Africa has been ranked at 140 out of 144 by the 2012-2013 Global Competitive Report with regards to quality of education. It is the lowest ranking compared with those of countries with weaker economies like Zimbabwe (30), Kenya (37), Zambia (39) and Swaziland (110).

It suffices to argue that the current education practices and provisioning tend to promote political expediency rather than quality in the broad sense. If the government can demonstrate through matriculation results that more learners have passed matric post 1994, it is plausible for citizenry to assume that the system is efficacious. Minister Angie Motshekga once announced that "SA education is on track to excellence", it was a political statement to pacify public discontent about the quality of the system. Minister's views demonstrate her department's narrow view of performance and benchmarking regimes. The fact that matriculation examination papers are pitched at "international standards" and evaluated by the Scottish Qualifications Authority and other entities does not make the system of high quality. The reality though, is that South Africa's education lags behind top-performing systems (Monyooe, 2013).

In an article "We have set the bar too low", Monyooe (2013:10) contests that: "Examinations do not test the system's efficacy but attempt to establish the competencies that pupils have acquired and mastered in a particular subject". Former British colonies adopted the O Level Examinations as a tool for quality assurance. Learner performance and achievement continued to be poor and the examinations were discontinued.

To illustrate the dangers of narrow view of performance regimes, Monyooe (2013:10) further argues that:

Fitting an internationally approved spare part into my 1990 "jalopy" does not change the quality of the vehicle in terms of the stringent quality assurance principles and procedures for the motoring sector. It merely, enhances the sectorial mechanics of the vehicle. Similarly, a terminal examination is not an appropriate tool to test quality related issues. A more holistic approach would suffice.

Examination papers are not reliable indicators of quality and efficacy given their narrow scope. uMalusi as the custodian of quality assurance has endorsed educational practices that compromise quality and excellence.

The secret to the Finnish system for being ranked among the high-performing systems in the OECD and PISA assessments in maths, science and reading can be attributed to what Darling-Hammond and Wentworth (2010:3) term "intensive investments in teacher education and major overhaul of the curriculum and assessment system". According to Darling-Hammond and Wentworth (2010) "Finland has no external standardized tests used to rank students or schools". On the contrary, South Africa uses terminal tests (matriculation) to sieve for entry to university or further education and training colleges.

South Africa's obsession with terminal examinations compromises the quality of education and it is at variance with robust debates on the efficacy of examinations (Darling-Hammond \& Wentworth, 2010; Darling-Hammond, 1994; Kivilu, 2004; Sahlberg, 2011). South Africa needs to find a balance between assessments, curriculum and teaching methodologies to give educational provisioning a much needed holistic approach and practices. According to Darling-Hammond and Wentworth (2010:35) South Africa needs to improve the accountability 
aspects of educational provisioning. South Africa might take a cue from Darling-Hammond's (1994) instructive views on educational reforms that:

Changing assessment forms and formats without changing the ways in which assessments are used will not change the outcomes of education. In order for assessment to support student learning, it must include teachers in all stages of the process and be embedded in curriculum and teaching activities, assessment must also be an integral part of on-going teacher dialogue and school development.

Similar views have been advanced by Sahlberg (2011:125) who cautions that:

...the insistence that nations follow the Global Educational Reform Movement - characterized by increased competition and choice, standardization of teaching and learning, tightening test-based accountability and merit based pay for teachers - may jeopardize schools' efforts to teach for the evolving knowledge society and for a sustainable future. This is not the best way to improve learning in our schools, and there is no evidence that it would improve the quality or enhance equity of education systems.

Sahlberg (2011) proposes inter alia, that schools should be staffed with professionally qualified teachers and considerable streamlining of bureaucratic regimes and functionalities. Furthermore, Sahlberg (2011: 125) perceives "sample-based testing, thematic assessments, reflective self-evaluations and emphasis on creative learning..." as plausible performance strategies South Africa could explore to enhance learner performance and achievement.

\section{Teacher Training and Development Programmes}

The publication of "An Introduction to Curriculum Research and Development" by Stenhouse (1975) changed global thinking and perspectives about curriculum design and development. It gave impetus to debates on plausible strategies to integrate curriculum development, teaching and research to improve quality in the provisioning of education. Stenhouse's (1975) publication led to a proliferation of other curriculum models with varied impact. In his writings, Stenhouse belabours the importance and impact of teachers as researchers. The notion of teachers as researchers underscores the expectation that schools should be staffed with qualified teachers steeped in curriculum development and teaching methodologies.

Clarity of roles and demarcation of responsibilities is crucial for the advancement of educational activities. A view cleverly articulated by Stenhouse (1975:6) reminds us that:

Prophets may teach private wisdom: teachers must deal in public knowledge ... A teacher is a man of learning skilled in teaching. He is qualified by virtue of his education and his training. He does not teach what he alone knows, letting his pupils in on secrets. On the contrary, his task is to help his pupils gain entry into commonwealth of knowledge and skills.

What Stenhouse articulates is instructive and relevant because of South Africa's weak teacher professionalization regimes and practices. Before 1994, curriculum design and development was the prerogative of bureaucratic technocrats to the exclusion of teachers. Teachers' exclusion from the locus of power and authority impacted on the quality of education and teaching in general. It turned schools into sites of conflict and protests. Schooling and education became dysfunctional. Although South Africa has made major strides to transform the educational landscape, teacher development remains critical and should be addressed to enhance quality education.

In his book "To Teach - the Journey of a Teacher", Ayers (2010) raises pertinent questions about the teaching profession. He questions why people still enrol to become teachers despite the profession's poor remuneration incentives and working conditions. Notwithstanding the inherent challenges within the profession, Ayers believes that people choose to teach for personal fulfilment and to change the lives of students so that they can function in a knowledge economy. In Finland, teaching is a high premium profession because of stringent recruitment, selection criteria and teacher education programmes. Sahlberg (2011:125) further argues Finland continues to be a top-performing country because schools are staffed with "well-prepared teachers, pedagogically designed schools, good school principals".

According to Sahlberg (2011) the Finnish system has benefited from clarity of vision and unanimous acceptance of the direction education must take to ensure that Finland remains competitive in international assessments and the knowledge economy. Unlike Finland, South Africa is a complex multicultural country still grappling with the legacy of apartheid. It does not have enough qualified teachers to change schools into 'hubs' of discovery and excellence. Various policies such as the Action Plan to 2014: Towards the Realisation of Schooling 2025 and 
Integrated Strategic Planning Framework for Teacher Education and Development in South Africa outline strategies to improve education and teacher development.

According to Sahlberg (2011:39):

The key success factor in Finland's development of a well-performing economy with good governance and a respected education system has been its ability to reach broad consensus on major issues concerning future directions for Finland as a nation...Educational policies that are based on the ideal of equal educational opportunities and that have brought teachers to the core of educational opportunities have positively impacted the quality of learning outcomes.

Sahlberg (2011:83) reminds us that successful education systems like the Finnish, integrate teacher education with research and classroom practices that enhance relevance. He further argues that:

Teacher education curricula are designed so that they constitute a systematic continuum from the foundations of educational thinking, to educational research methodologies, and then on more advanced fields of educational sciences. Each student thereby builds an understanding of systemic interdisciplinary nature of educational practice... The Finnish teacher education program represents a spiral sequence of theoretical knowledge, practical training, and research -oriented enquiry of teaching.

South Africa has implemented a three-pronged approach to teacher development namely, (a) orientation to the curriculum and assessment policy statement (CAPS), (b) short-course interventions and (c) qualification programme and unit standard interventions. The department of education in partnership with public universities have agreed to a teacher training development programme implemented through the Funza Lushaka Bursary Scheme. The training seems ad hoc since universities decide on their own programmes and selection criteria. Unlike the Finnish and Singaporean models where teachers are tested for competency on (a) high levels of literacy and numeracy (b) strong interpersonal and communication skills (c) problem-solving (d) willingness to learn and motivation to teach. Matriculation pass is the key criterion for university admission. In some cases, universities have to administer bridging courses to bring students up to speed with discipline content.

South Africa's screening process for teacher selection and lags behind that of Finland in many aspects such as (a) qualification verification (b) assessment tests (literacy \& numeracy) (c) monitoring teachers during initial training and if found wanting in skills, they are removed from the programme. Finland has raised the "status of the teaching profession by requiring that all teachers possess a master's degree”. Similarly, Singapore has enhanced "academic rigours of teacher education courses and provides the entitlement of 100 hours fully-paid professional development training each year" for teachers to improve their teaching and assessment skills. South Africa has poor pre and in-service training programmes and remuneration incentives that fail to retain high performing teachers in the system. The minimum qualification to be employed as a teacher in South Africa is a certificate for the grade $\mathrm{R}$ level. Literatureon teacher education attributes high performing schools to the presence of professionally qualified teachers (see Darling-Hammond \& Wentworth, 2010; Monyooe, 2005; Sengul, Katranci \& Bozkus, 2013; Chisholm \& Vally, 1996). It is important for South Africa to explore robust interventions to enhance quality of education.

Both Darling-Hammond and Wentworth (2003:2) remind us that "Qualified teachers are a critical national resource that requires federal investment and cross-state coordination". They further caution against the practice of taking short cuts to teacher development by either lowering "standards" or use of "quick-fix" programmes that do not enhance quality". Darling-Hammond and Sykes (2003) argue that the "quick-fix" approach to address teacher shortage is not sustainable and impacts on the quality of the teacher graduates and the profession in general.

Both Finland and Singapore have raised the profile of the teaching profession by requiring teachers to possess the highest qualifications (master's degree) and strengthening the quality and scope of teacher education programmes. For South Africa to match international practices on teacher education, it must deploy what Darling-Hammond and Sykes (2003:2) term: "new and rigorous alternate-certification programs based on careful selection, purposeful preparation, and intensive mentoring and practice teaching that are successful in preparing mid-career recruits from other fields". Highly qualified teachers allow school principals to focus and strengthen (a) professional guidance to enhance tuition (b) regularly monitor classroom activities and learner progression (c) promote parental involvement and (d) implement new ideas to enhance quality education and leverage resources for infrastructure development. 
Research confirms that when schools are staffed with professionally qualified teachers learner performance and overall management improve (Sahlberg, 2011; Darling-Hammond \& Sykes, 2003; Darling-Hammond \& Wentworth, 2010; Monyooe, 2005; Chisholm \& Vally, 1996; Singul, Katraci \& Bozkus, 2013; NG, 2008). South Africa's schools might not change and improve "without fundamentally raising the quality of teachers and teaching". Robust teacher development programmes that are responsive to South Africa's context should be deployed. Occupational conditions, remuneration and management of schools must be enhanced to attain quality. Efficient coaching and mentoring to support less experienced teachers and school principals can enhance quality.

\section{Alliances and Politics of Teacher Unionization}

Following the 2009 Teacher Summit held in South Africa both the department of basic education and teacher unions (federations) signed the Integrated Strategic Planning Framework for Teachers' Education and Development (ISPFTED) 2011-2025. The agreement identified the following as the major challenges to teacher education and development (TED):

- A lack of access to quality TED opportunities for prospective and practising teachers;

- A mismatch between the provision and demand for teachers of particular types;

- The failure of the system to achieve dramatic improvement in the quality of learning and teaching in schools;

- A fragmented and uncoordinated approach to TED;

- The tenuous involvement of teachers, their organizations and other role players; and

- Inefficient and poorly monitored funding mechanisms (p24).

Whilst the framework "places teachers firmly at the centre of all efforts to improve capacity and effectiveness", the school environment remains highly unionized given that $70 \%$ of teachers are unionized and prone to conflicts and protests as teachers assert their occupational rights for improve working conditions. The agreement binds both the department and teacher federations to work together to improve working conditions for teachers across the country. It suffices to argue that the partnership (agreement) has not brought about the much needed stability in schools due to constant protests and strikes for better remuneration by teachers.

The public sector unions have transformed management of the labour environment (Letseka, Bantwini and King-McKenzie, 2012; Zegarra \& Ravina, 2003). It has given unionized entities an opportunity to assert their labour interests in pursued of improved working conditions. Elsewhere, the Organization for Economic Cooperation and Development (OECD) confirms that: "Teachers in Ireland are highly unionised with 98\% of primary teachers and $91 \%$ of post primary teachers belonging to a teacher union". Based on the numbers, the Irish teachers have unprecedented influence on provisioning of education. Similar views have been articulated by Kerchner (2004). A fundamental question arising from Kerchner's observation relates to how union and alliance practices have influenced education and management of school environment.

Leeds (2003:427) makes interesting observations about alliance politics namely that: "Alliance commitments affect decisions to initiate disputes, but because different alliances involve different promises to different actors, alliances can have different effects. Some alliances deter open hostilities whereas others provide the assurances necessary to facilitate attack". What Leeds postulates resonates with teacher union experiences in South African in that "SADTU organizes teachers at the expense of teaching and learning in a country whose system has been described as "a crisis" and "a national disaster" whose schools are dysfunctional" (Letseka et al, 2012:1197). Letseka et al, (2012:1198) further argue that:

Politicians are under constant pressure to seek more diplomatic solutions to public-sector unions' demands in order to avoid tension and protracted labour disputes. History shows that politicians who become confrontational soon realize that they do so at their own peril. Greek education minister Marietta Giannakou lost her seat for insisting on teacher accountability...In the US Michelle Rhee, chancellor of the school system in Washington DC closed failing schools, fired more than 200 ineffective teachers and principals and advocated merit pay. In response the unions used their political muscles to bring about her resignation.

According to Letseka et al, (2012:1197) the influence of teacher unionization is South Africa is different from global experiences in that:

The largest union, the South African Democratic Teachers Union (SADTU) is affiliated to the Congress of South African Trade Union (COSATU). The latter is a partner in the ruling tripartite alliance that includes the National African Congress (ANC) and the South African Communist Party (SACP). 
World-wide public-sector unions are known to prop up left wing political organizations. SADTU is no exception.

According to literature, unionized teachers in South Africa spent far less time teaching learners than their international counterparts (Chisholm, et al, 2005; Makola, 2005; Bloch, 2009; Centre for Development and Enterprise, 2007; Kerchner, 2004; Leeds, 2003). Research demonstrates that highly motivated teachers and professionally managed school environment contribute to quality education (Heystek \& Lethoko, 2001; Chisholm \& Vally, 1996).

According to literature (Pansiri \& Bulawa, 2013; Darling-Hammond \& Sykes, 2003), there is global acknowledgement that teaching as a profession, has diminished both in stature (reputation) and content. Pansiri and Bulawa (2013:242) attribute this situation to: "partly due to the growing perceptions of the low status that is attached to the teacher and the teaching profession. The major factors contributing to the poor status of teachers were the public service reforms which divide teachers instead of uniting them".

To address this challenge, Pansiri and Bulawa (2013) argue that a more open and collaborative engagement between teacher unions and government can alleviate the challenges. A view succinctly delineated by Leeds (2003:437) who argues that "because alliances affect the decisions of both adversaries and allies, and because alliances may contain a variety of commitments, different agreements can have different effects...Aggregating these effects can mask any relationship in large empirical studies".

Similar views have been expressed by Darling-Hammond and Sykes (2003:1) that:

The concern with teacher quality has been driven by a growing recognition, fuelled by accountability research evidence, of how critical teachers are to student learning. To acquire and retain high-quality teachers in our Nation's classrooms will require substantial policy change at many levels.

According to Fullan (1993) a lot can be leveraged through policy changes that influence practice on the ground. In the context of schools an intelligent allocation, utilization and management of resources is paramount. Literature suggests that high performing education systems have clarity of vision and presence of mind to deal with contradictions of alliance politics and unionization (Ayers, 2010; Hargreaves \& Fink, 2004; Darling-Hammond \& Sykes, 2003; Cutterbuck, 1995).

Alliance politics and teacher unionization will continue to dominate South Africa's schooling environment for foreseeable future. Some interesting lessons could be learnt from efficacious systems like Finland, Singapore that South Africa might deploy to enhance the quality of education in the broad sense.

\section{Conclusion}

Notwithstanding a plethora of policies formulated post 1994, South Africa still grapples with issues of quality in education, for instance, matriculation results, teacher education, curriculum, teaching and assessment strategies and performance benchmarks. Rigorous training and development in areas of school governance, leadership and management would improve quality and overall management of the school environment. Furthermore, a more strategic coordination of policy implementation and management interfaces at systemic and operational levels has the potential to improve the quality of South Africa education.

\section{Acknowledgements}

We acknowledge financial support for the publication of this article from the National Research Foundation (NRF) South Africa. The views expressed in the article are those of the authors and do not represent the organization they are affiliated to.

\section{References}

Ayers, W. (2010).To Teach- the journey for a teacher. Teachers College Press: New York.

Bloch, G. (2009). The toxic mix: What's wrong with SA's schools and how to fix it? Cape Town: Tafleberg Publishers.

Bolin, F. S. (1989). Empowering Leadership. Teachers College Record, 9(7), 81-96.

Centre for Development and Enterprise. (2007). Doubling for growth: Addressing the maths and science challenge in South Africa's schools. Johannesburg: CDE.

Centre for Development and Enterprise. (2011). Schooling Reform is Possible: Lessons for South Africa from international experience. The Centre for Development and Enterprise, Johannesburg, South Africa. 
Chisholm, L., \& Vally, S. (1996). Report of the Committee on the Culture of teaching and learning. Pretoria: Ministry of Education.

Chisholm, L., Hoardley, U., Kivilu, M., Brooks, H., Prinsloo, C., Kgobe, A., Mosia, D., Narsee, H., \& Rule, S. (2005). Educator workload in South Africa. Cape Town: HSRC Press.

Constitution of South Africa. (Act 108 of 1996). Government Printers: Pretoria, South Africa.

Cutterbuck, D. (1995). The power of empowerment: Release the Hidden Talents of your employees. London: Kogan Page.

Darling-Hammond, L., \& Sykes, G. (2003). Wanted; A National Teacher Supply Policy for Education. The Right way to meet the "Highly Qualified Teacher" Challenge. Education Policy Analysis Archives, 11(33), $1-55$.

Darling-Hammond, L. (1994). Performance - based assessment and educational equity. Harvard Educational Review, 64(5), 30.

Darling-Hammond, L., \& Wentworth, L. (2010).Benchmarking learning systems: Student performance assessment in international context. Stanford, CA: Stanford University, Stanford Center for Opportunity Policy in Education in http://www.edpolicy.stanford.edu.

Darling-Hammond, L., \& Bullmaster. (1997). The Changing Social Context of Teaching in the United States. In B. J. Biddle (eds.) International Handbook of Teachers and Teaching Volume 2. Kluwer Academic Publishers: Doredrecht.

Department of Education. (1996). The National Education Act .Government Press: Pretoria, South Africa.

Department of Education. (1996). The South African Schools Act. Government Press: Pretoria, South Africa.

Department of Education. (1998). The Employment of Educators Act. Government Printers: Pretoria, South Africa.

Department of Education. (2000). The White Paper on Early childhood Development. Government Printers: Pretoria, South Africa.

Department of Education. (2001). The Education White Paper 6 on Inclusive Education. Government Printers: Pretoria, South Africa.

Department of Basic Education. (2011). Annual National Assessments results. Government Press: Pretoria, South Africa.

Department of Basic Education. (2011). The National Curriculum Statement Grades R-12. Government Printers: Pretoria, South Africa.

Department of Education. (2001). The General and Further Education and Training Quality Assurance Act. Government Printers: Pretoria, South Africa.

Department of Basic Education. (2010). Action Plan to 2014: Towards the realisation of Schooling 2025 (published as Government Notice 752 of 2010). Government Press: Pretoria, South Africa.

Department of Basic Education. (2010). The Delivery Agreement for Basic Education Sector. Government Press: Pretoria, South Africa.

Department of Education. (2009). Annual Report 2008/09. Government Press: Pretoria, South Africa.

European Commission. (2007/08). The education system in Finland. Eurybase, the Information Database on Education Systems in Europe.

Fullan, M. (1993). Change Forces: Probing the depths of Educational Reforms. London: Falmer Press.

Hargreaves, A., \& Fink, D. (2004). The Seven Principles of Sustainable Leadership. Educational Leadership, $61(7), 8-13$.

Hartshorne, K. (1992). Crisis and Challenge: Black Education 1910 - 1990. Cape Town: Oxford University Press.

Heystek, J., \& Lethoko, M. (2001). The contribution of teacher unions in the restoration of teacher professionalism and the culture of learning and teaching. South African Journal of Education, 21(4), 222-228. 
Kerchner, C. T., \& Baroi, D. (2004). The Relationship between Teacher Unionism and Educational Quality: A Literature Review.

Kivilu, M. (2004). Politics of public examinations in Africa. Paper presented at the 22nd Annual Conference for Educational Assessment in Africa 13-17 September, Gaborone, Botswana.

Leeds, B. A. (2003). Do alliances deter aggression? The influence of military alliances on the initiation of militarized interstate disputes. American Journal of Political Science, 47(3), $427-439$. http://dx.doi.org/10.1111/1540-5907.00031

Letseka, M., Bantwini, B., \& King-McKenzie, E. (2012). Public-Union Sector Politics and the Crisis of Education in South Africa. Creative Education, 3(7), 1197-1204. Published online November 2012 in Scie Res (http://www.SciRP.org/Journal/ce).

Makola, C. P. (2005). Factors affecting teaching and learning in South African public schools. Educational Labor Relations Council. Cape Town: HSRC Press.

Monyooe, L. A (2005). Inclusive Education and Training Systems: Illusion or Reality? The Story of Nothemba, $13(3), 1-24$.

Monyooe, L., \& Ledwaba, S. (2004). Information and Communication Technologies for Women Empowerment: South Africa's Unfinished Agenda in (http://itdl.org/journal/sep_04/article01.htm).

Monyooe, L. (2013). Quality Education in South Africa. In T.S. Mwamwenda, \& P. Lukhele-Olorunju, P. (Eds.,) (2013). The Triumph and Prosperity of Education in Africa, Africa Institute of South Africa: Pretoria.

Mwamwenda, T. S., \& Lukhele-Olorunju, P. (Eds.,) (2013). The Triumph and Prosperity of Education in Africa, Africa Institute of South Africa: Pretoria.

NG, P. T. (2008). Educational reform in Singapore: from quantity to quality. Education Research on Policy and Practice, 7, 5-15. http://dx.doi.org/10.1007/s10671-007-9042-x

OECD Report. (2007). Improving School Leadership-OECD Project- Background Report Ireland in (http://www.oecd.org/edu/schoolleadership).

Pansiri, N. O., \& Bulawa, P. (2013). An Analysis of Teachers' Status in Crisis of public service reforms in Botswana. European Journal of Business and Social Sciences, 1(12), 233 -244.

Prew, M. (2012). Rethinking the building blocks. Mail \& Guardian November 2 to 8.

Sahlberg, P. (2011). Finnish Lessons - What can the world learn from educational change in Finland. Teachers College Press: New York.

Sengul, S., Katranci, Y., \& Bozkus, F. (2013). Learning Styles of Prospective Teachers: Kocaeli University Case. $3(2), 1-12$.

Smith, D. D. J., \& Schalekamp, S. (1997). Restoring a culture of teaching and learning. Results of phase one of a project in the West Rand Department of Education. Paper presented at EASA Conference, January, RAU, Johannesburg.

Stenhouse, L. (1975). An Introduction to Curriculum Research and Development. Heinemann: London.

The Finnish Matriculation Examination. (2008). Retrieved July 4, 2013, from http://www.ylioppilstutkinto.fi/en/index.html.

The Presidency. (2012). National Development Plan 2030. Government Press: Pretoria, South Africa.

Tomasevski, K. (2003:18). Economic Social and Cultural Rights: The right to education. United Nations Report on Commission on Human Rights in http://www.crop.org/workshops/files/000070-CP-CROP-NFU.

World Economic Forum. (2012). The Global Competitive Report 2012/13. Geneva: World Economic Forum.

Zegarra, E., \& Ravina, R. (2003). Inter-American Development Bank. Research Department. Latin American Research Network in (http://www.iadb.org/res).

\section{$(\mathrm{cc}) \mathbf{E Y}$}

This work is licensed under a Creative Commons Attribution 3.0 License. 